\title{
Online Classrooms During COVID-19 Pandemic: A Survey of Industrial Engineering Instructors in Indonesia
}

Ardiyanto Ardiyanto, $\mathrm{PhD}$

Universitas Gadjah Mada, Yogyakarta, Indonesia

(iD) https://orcid.org/0000-0002-7907-5237

Taufik Mulyadin, $\mathrm{PhD}$

Binus University, Jakarta, Indonesia

Adinda Mutiara Santi

Universitas Gadjah Mada, Yogyakarta, Indonesia

I Gusti Bagus Budi Dharma, $\mathrm{PhD}$

Universitas Gadjah Mada, Yogyakarta, Indonesia

Contact: ardiyanto@mail.ugm.ac.id

\section{Abstract}

Objectives: The purpose of this descriptive study was to understand the instructional methods, quality, and challenges in online instruction as industrial engineering instructors in Indonesia transitioned from face-toface to fully online instruction during the COVID-19 pandemic.

Methods: Instructors were invited to complete a survey that requested perceptions on methods, perceived quality, and challenges regarding course delivery and assessment in their online classrooms.

Results: Despite the fact that more than half of the participants (59\%) had some training, the majority (63\%) reported that they had no experience in conducting online classrooms. Furthermore, more than $50 \%$ of the participants described the quality of the course delivery and assessment as the same or inferior to traditional classrooms. Most participants reported having an issue with measuring student involvement or gaining class interaction. Regarding the course assessment, the vast majority of the participants reported concerns about integrity issues associated with assignments and exams.

Implications for Practice and Conclusion: Since instructors reported intention to continue online instruction post-pandemic, industrial engineering programs can begin strengthening the online learning infrastructure and providing some training to the instructors to minimize the discrepancies between face-toface and online instruction. 
Keywords: COVID-19 pandemic, online classrooms, Indonesia, industrial engineering instructors

Submitted: December 24, 2020 | Accepted: April 21, 2021 | Published: June 11, 2021

\section{Recommended Citation}

Ardiyanto, A., Mulyadin, T., Mutiara Santi, A., \& Dharma, I G. B. D. (2021). Online classrooms during COVID-19 pandemic: A survey of industrial engineering instructors in Indonesia. Higher Learning Research Communications, 11(1) 27-46. https://doi.org/10.18870/hlrc.v11i1.1232

\section{Introduction}

The novel coronavirus disease (COVID-19) that was initially found in China also spread to Indonesia. The first case of COVID-19 in Indonesia was recorded on March 2, 2020 (Gorbiano, 2020). Consequently, some cities had to implement social restrictions to curb the spread of the virus (COVID-19 Management Task Force, 2020).

To ensure student safety, the Indonesian government required colleges and universities to halt all face-to-face learning and transition instruction online (Ministry of Education and Culture, 2020b). This policy has affected entire programs on campuses, including industrial engineering (IE). The sudden changes may have been disruptive, because Indonesian colleges and universities were typically not designed to carry out online programs. The only higher education institution in Indonesia that was established to promote and conduct distance learning was The Open University of Indonesia or Universitas Terbuka (Belawati, 2005; Harsasi, 2015), which was initially established to train schoolteachers to improve teaching quality and fulfill increasing teacher demand in Indonesia.

Some attempts to understand the implementation and challenges in conducting online classrooms during the pandemic had been carried out in several higher education institutions. As reported by Roy and Covelli (2020), institutions with prior online teaching experience could adjust to the instructional disruption easier due to technological and pedagogical infrastructure readiness. However, institutions with less familiarity in conducting online classrooms, like most colleges and universities in Indonesia, could face more hurdles.

Realizing that some gaps existed in understanding the challenges associated with the transition to online learning in the IE community during the COVID-19 pandemic, this survey-based study was critical. The primary objective was to discover the selected methods, perceived quality, and challenges associated with course delivery and assessment. The other objective was to understand the faculty's attitudes toward and experiences in their online classrooms.

\section{Literature Review}

\section{Industrial Engineering Education in General and IE Education in Indonesia}

Industrial engineering (IE) courses can be distinguished by four groups of subjects: basic science and mathematics, general engineering sciences, industrial engineering sciences, and general education (Nguyen \& Nguyen, 2018). Basic science and math subjects consist of calculus and other natural science related courses. Computer programming and engineering drawing are the two examples of the courses that fall into the general engineering sciences category. Some IE sciences can include courses related to operations research, engineering economics, human factors, and supply chain management (Institute of Industrial \& Systems Engineers, 2019). Academic writing and English are two of the most common general education subjects found in IE programs. 
Due to the different laboratory work characteristics, IE instructors may encounter fewer challenges than instructors in other engineering fields when conducting the online classrooms. Some IE courses that require laboratory work are statistics, programming, engineering drawing, ergonomics, and simulations (Adams, 1984; Ilman, 2020; Kulkarni et al., 2017). Hence, most laboratory work in IE programs could be completed in a computer lab. This could lead to a different level of instructional challenges than other programs such as electronics engineering programs that require more exposure to instrumentation during laboratory work (Siegel, 2002).

In Indonesia, IE education was first introduced by an Ohio-trained industrial engineer, Dr. Matthias Aroef, in the early 1960s (Savitri, 2018). IE has become one of the most popular and competitive engineering programs in Indonesia. The high passing grades among several public universities indicated the popularity of IE programs in Indonesia (Prodjo, 2020). Furthermore, some students consider IE graduates to have broad career options, making this program more favorable among high school graduates.

Most IE programs are offered in colleges situated in Java Island inhabited by $57 \%$ of the Indonesian population (Central Bureau of Statistics, 2020). Due to the population density on this island, many postsecondary institutions were established. Unsurprisingly, almost half (48\%) of the Indonesian universities and colleges can be found on this island (Ministry of Research, Technology, and Higher Education, 2018).

\section{Online Classrooms in Indonesia Higher Education}

Fraudulent practices by degree mills could be one reason why only a few institutions offered online programs in Indonesia in the past. These practices created skepticism regarding online programs among Indonesian academicians and government officials. Consequently, the Indonesian government has been cautious in pushing colleges and universities to have online programs (Sulistyo-Basuki, 2007).

Despite the fact that most colleges and universities in Indonesia currently do not have any online programs, some have started adopting blended learning in their classrooms. Through this approach, students can access some lectures or course materials asynchronously or synchronously through online media while still attending the face-to-face sessions (Surjono et al., 2017). The increased use of blended learning in Indonesia has improved the e-learning infrastructure. Some universities in Indonesia started putting investment in developing their self-managed learning management system (LMS) or adopting a web-based LMS (Zainuddin \& Keumala, 2018).

In addition to the increased use of blended learning, many private and public educational institutions had started offering massive online open courses (MOOCs) during the last decade (Ginting et al., 2020). The institutions that initiated such programs believed MOOCs could grant society more access to high-quality courses for free or at a very affordable fee (Nurhudatiana et al., 2019). However, some MOOC instructors still encountered challenges, including low participant engagement and the difficulties in recording and editing asynchronous lecture videos (Sari et al., 2020).

Due to the high dependency of online learning on technology, the uneven quality of the internet across Indonesia could create some challenges when conducting online classrooms (Zuhairi et al., 2006). Less dense regions in Indonesia, such as Papua and Central Sulawesi, had less telecom infrastructure than other areas such as Central Java, East Kalimantan, and North Sumatra (Sujarwoto \& Tampubolon, 2016). Variation in infrastructure has also been observed in other developing countries, including Nigeria (Eastmond, 2000; Olori \& Dessy, 2017). Internet access availability notwithstanding, some Indonesian students had low purchasing power (Luschei et al., 2008). Consequently, they could not afford good internet access to support learning activities. 
Another challenge faced in the implementation of online classrooms in Indonesia was lower computer literacy among instructors. Although most Indonesian instructors were familiar with some word processors and presentation programs (Son et al., 2011), only a few could utilize advanced instructional technologies, particularly those associated with video recording and editing to support online learning (Watts, 2016).

\section{Faculty Barriers to Online Classrooms}

The first barrier to online classrooms could come from the faculty's unique perspective of such teaching approaches. Faculty who have only experienced traditional instruction in their education may be more hesitant to adopt online learning due to the unfamiliarity of the pedagogical and technological approaches associated with online instruction (Bacow et al., 2015; Myers et al., 2004). Some of them also have inaccurate assumptions regarding limited in-person experience and skepticism regarding the achievement of learning outcomes acquired through distance education (Bunk et al., 2015; Palmer et al., 2014). Some may also fear that online instruction could diminish the need for instructors in the future (Bacow et al., 2015).

Due to the different levels of computer literacy across faculty, inadequate technological skills could present additional barriers to online instruction adoption (Niebuhr et al., 2014; O’Doherty et al., 2018). To help with those challenges, universities may provide generous technical support to the instructors (Bacow et al., 2015). The support could include multiple training sessions as well as one-to-one assistance for faculty members designing online courses (Orr et al., 2009).

Limited online classroom infrastructure could be another barrier to determining the success of such programs (Bediang et al., 2013). The main infrastructure required for online instruction includes information technology platforms such as learning management systems and cloud computing applications (Dong et al., 2009). Tools for gaining student involvement, including gamification platforms, could also be another important aspect of online classroom infrastructure (Gokbulut, 2020).

\section{Purpose of the Study}

The purpose of this descriptive study was to collect information on the selected methods, perceived quality, and challenges associated with course delivery and assessment among Indonesian instructors at IE programs during the emergency transition from face-to-face to online instructions forced by the COVID-19 pandemic. This study was also aimed at investigating the Indonesian IE instructors' experience and attitude toward online classrooms.

\section{Methods}

\section{Participants}

An invitation was sent via e-mail to 300 instructors of IE programs at the post-secondary level in Indonesia. The candidates were randomly selected from the faculties from 45 Indonesian IE programs with searchable websites. The governmental regulations required an undergraduate program to have six or more permanent faculty members (Ministry of Research, Technology, and Higher Education, 2015). Hence, we invited at least six instructors from each program. Consent was obtained from all participants prior to the participation in the study. The protocol was approved by the Research and Community Service Committee of the authors' institution.

\section{Instrumentation}

A survey was used to collect descriptive data about course delivery and assessment methods during the emergency transition period forced by the COVID-19 pandemic between March and July 2020. The survey was conducted 
using Bahasa Indonesia, the official language of Indonesia (the English translation of the survey is provided as an appendix). Before administering the survey using the Google online survey platform, a pilot study was conducted that involved three IE instructors having different institutional affiliations from the study authors.

Inquiries regarding course assessment were divided into two sections: non-exam and exam-related questions. The survey also asked the participants to rate the perceived quality of the conducted online classrooms compared to face-to-face instructions performed prior to the pandemic. Also, the survey asked about current challenges of the online classrooms. The choices available in the questions were determined based on brainstorming sessions with five IE instructors in the first author's institution.

The participants were asked to provide their demographic, academic, and institutional backgrounds. Demographic inquiries included questions regarding gender and age. The inquiries associated with academic and institutional background requested some information on the participants' highest degree, years of teaching, academic grades, as well as locations and accreditation ranks of the participants' institutions. Several questions (Questions 11-15 in the appendix), adapted from Britt (2006), were also asked to understand the experiences related to teaching in online classrooms. Inquiries regarding experiences were used to gather information on participants' prior online teaching experience and training regarding online classrooms before the pandemic. We also asked some questions regarding their perceived level of difficulty in teaching online and the challenges encountered.

\section{Data analysis}

The survey results on participants' demographics, academic and institutional background, as well as the experiences and attitude regarding online classrooms, were presented using frequency and percentages. A similar approach was also performed for the survey results on methods, perceived quality, and challenges of the course delivery and assessments. In each question of the survey, we provided the participants with an open-ended choice for accommodating responses outside the available options. In analyzing them, two of the study authors would first analyze whether they matched with available choices. If the analysis concluded that the responses did not fall to any choices, the authors would list them individually. Data analysis was performed using Microsoft Excel.

\section{Results}

Table 1 provides information on the demographic questions. Out of the total invited candidates, $78 \mathrm{IE}$ instructors returned completed surveys for a response rate of $26 \%$. Approximately $41 \%$ of the sample was female. Mean age of the participants was 43 years $(S D=11)$. Furthermore, $65 \%$ of the participants had a master's degree, and the rest reported having a $\mathrm{PhD}$. More than half of the participants had been teaching for less than 15 years. The majority (63\%) were professors, with about $28 \%$ reporting lecturer status. Most (79\%) were from IE programs located on the island of Java. More than half of the participants came from institutions that the accreditation rank was higher than or equal to B ("Very Good").

Table 1: Participant Demographics, Academic, and Institutional Background

\begin{tabular}{ll}
\hline Demographic & n (\%) \\
\hline Gender & \\
\hline Female & $32(41 \%)$ \\
Male & $45(58 \%)$ \\
Unreported & $\mathbf{1}(1 \%)$ \\
\hline Age & \\
\hline$<30$ & $8(10 \%)$
\end{tabular}




\begin{tabular}{ll}
\hline Demographic & n (\%) \\
\hline $31-40$ & $30(39 \%)$ \\
$41-50$ & $22(28 \%)$ \\
$51-60$ & $14(18 \%)$ \\
$>61$ & $4(5 \%)$ \\
\hline Degrees & \\
\hline MS & $51(65 \%)$ \\
PhD & $27(35 \%)$ \\
\hline Years of teaching & \\
\hline$\leq 5$ & $21(27 \%)$ \\
$6-10$ & $7(9 \%)$ \\
$11-15$ & $16(20 \%)$ \\
$16-20$ & $12(15 \%)$ \\
$21-25$ & $13(17 \%)$ \\
$>26$ & $9(12 \%)$
\end{tabular}

\begin{tabular}{|c|c|}
\hline \multicolumn{2}{|l|}{ Academic Grades } \\
\hline No grade & $6(8 \%)$ \\
\hline Lecturers & $22(28 \%)$ \\
\hline Assistant Professors & $31(40 \%)$ \\
\hline Associate Professors & $16(20 \%)$ \\
\hline Professors & $2(3 \%)$ \\
\hline Unreported & $1(1 \%)$ \\
\hline \multicolumn{2}{|l|}{ Locations of Institutions } \\
\hline Celebes Island & $2(3 \%)$ \\
\hline Java Island & $62(79 \%)$ \\
\hline Madura Island & $1(1 \%)$ \\
\hline Sumatera Island & $11(14 \%)$ \\
\hline Unreported & $2(3 \%)$ \\
\hline \multicolumn{2}{|c|}{ Accreditation Ranks of the Participants Institution* } \\
\hline A or Unggul (Excellent) & $32(41 \%)$ \\
\hline B or Baik Sekali (Very Good) & $39(50 \%)$ \\
\hline C or Baik (Good) & $6(8 \%)$ \\
\hline Unreported & $1(1 \%)$ \\
\hline
\end{tabular}

\section{Faculty Experiences and Attitudes Regarding Online Classrooms}

Table 2 contains information on faculty experiences related to the online classroom. About $37 \%$ of the participants had taught online courses before the COVID-19 pandemic, while 59\% reported having experience attending online teaching training. Furthermore, $86 \%$ felt qualified to conduct online classrooms, and $73 \%$ planned to continue using it after the pandemic. Regarding the perceived level of difficulties to teach online during the pandemic, most participants reported that it was difficult (26\%) or neutral (33\%). About 73\% reported difficulty conducting online classrooms due to limited communication with the students. The majority 
of participants (56\%) highlighted inadequate internet access by some students as the other challenge regarding managing online classrooms. Moreover, some participants (40\%) reported facing challenges associated with limited preparation time transitioning from traditional to online classrooms forced by the pandemic.

Table 2: Faculty Experiences and Attitudes Toward Online Classrooms

\begin{tabular}{lc}
\hline & n (\%) \\
\hline Conduct online classrooms prior to the COVID-19 pandemic? & $29(37 \%)$ \\
\hline Yes & $49(63 \%)$ \\
No & $46(59 \%)$ \\
\hline Trained to carry out online classrooms prior to the COVID-19 pandemic? & $32(41 \%)$ \\
\hline Yes & \\
No & $67(86 \%)$ \\
\hline Feel qualified to conduct online classrooms? & $10(13 \%)$ \\
\hline Yes & $1(1 \%)$ \\
No & $57(73 \%)$ \\
\hline Future plans to continue conducting online classrooms after the COVID-19 pandemic? \\
\hline Yes & $20(26 \%)$ \\
No & $1(1 \%)$ \\
\hline Unreported & $2(3 \%)$ \\
\hline Level of difficulty experienced when conducting online classrooms & $20(26 \%)$ \\
\hline (Very difficult) & $26(33 \%)$ \\
\hline (Difficult) & $23(29 \%)$ \\
4 (Easy) & $7(9 \%)$ \\
\hline (Very Easy) & $57(73 \%)$ \\
\hline Types of challenges encountered when conducting online classrooms during the pandemic \\
\hline Limited communication with the students & $44(56 \%)$ \\
Lack of student access to the internet & $31(40 \%)$ \\
Limited preparation time & $18(23 \%)$ \\
\hline Enfamiliarity with the technology & $15(19 \%)$ \\
\hline & $2(3 \%)$ \\
\hline Efforts to prepare online teaching materials & $1(1 \%)$ \\
\hline
\end{tabular}

\section{Course Delivery}

Table 3 contains information related to course delivery. The largest percentage (24\%) of instructors used a combination of synchronous and asynchronous methods as well as messaging apps, followed by $22 \%$ of participants who combined synchronous and asynchronous methods without messaging apps for delivering the courses. Most participants used conferencing platforms such as Zoom and Google Meet for delivering the course synchronously. Meanwhile, asynchronous learning was delivered using either Google Classroom or university-managed learning management systems. More than $70 \%$ described their perceived quality of the course delivery based on the selected methods they chose as either slightly poor or inferior to the face-to-face instructions. The highest percentage of the reported challenges was related to the instructor difficulties in measuring student involvement in the online classroom setting. Also, most participants (68\%) highlighted that the classroom became less interactive. 
Table 3: Faculty Experiences and Attitudes Toward Online Classrooms

\begin{tabular}{|c|c|}
\hline Items & n (\%) \\
\hline \multicolumn{2}{|l|}{ Course delivery methods } \\
\hline Combination of synchronous, asynchronous platforms and messaging apps & $19(24 \%)$ \\
\hline Combination of synchronous and asynchronous platforms & $17(22 \%)$ \\
\hline Synchronous single platform & $12(15 \%)$ \\
\hline Asynchronous single platform & $9(12 \%)$ \\
\hline Combination between synchronous platforms and messaging apps & $6(8 \%)$ \\
\hline Synchronous multiple platforms & $5(6 \%)$ \\
\hline Combination between asynchronous platforms and messaging apps & $5(6 \%)$ \\
\hline Asynchronous multiple platforms & $2(3 \%)$ \\
\hline Messaging apps such as WhatsApp & $3(4 \%)$ \\
\hline \multicolumn{2}{|c|}{$\begin{array}{l}\text { Perceived quality of the course delivery process in comparison to traditional (face-to-face) } \\
\text { classrooms }\end{array}$} \\
\hline Better & $4(5 \%)$ \\
\hline Slightly better & $7(9 \%)$ \\
\hline No difference & $12(16 \%)$ \\
\hline Slightly worse & $47(60 \%)$ \\
\hline Worse & $8(10 \%)$ \\
\hline \multicolumn{2}{|l|}{ Challenges in the course delivery process } \\
\hline Difficulties in measuring the students' involvement during the lectures & $55(71 \%)$ \\
\hline Lectures became less interactive & $53(68 \%)$ \\
\hline Lectures became boring due to difficulties in telling jokes during online lessons & $40(51 \%)$ \\
\hline Instructors found it difficult to provide examples, particularly in mathematics & $31(40 \%)$ \\
\hline Some concepts became more difficult to demonstrate or explain & $27(35 \%)$ \\
\hline Some technical errors such as forgetting to unmute the mic were often encountered & $25(32 \%)$ \\
\hline $\begin{array}{l}\text { Instructors encountered issues with their internet connection during the process of } \\
\text { course delivery }\end{array}$ & $4(5 \%)$ \\
\hline
\end{tabular}

\section{Non-Exam-Related Assessment}

Individual paper assignments appeared to be the most favorable assessment method (55\%). A majority (68\%) reported using the same assessment methods as in face-to-face instructions. Furthermore, more than half of the participants stated that their perceived quality of the course assessment was either slightly lower or much poorer than traditional classrooms. A large majority (79\%) of participants described that they had hesitancy about whether the assignments were written by the students individually. See Table 4 for detailed responses. 
Table 4: Methods, Perceived Quality, and Challenges of the Non-Exam-Related Course Assessment During the COVID-19 Pandemic

\begin{tabular}{|c|c|}
\hline Items & n (\%) \\
\hline \multicolumn{2}{|l|}{ Non-exam related course assessment methods } \\
\hline Individual paper assignment & $43(55 \%)$ \\
\hline Group paper assignment & $36(46 \%)$ \\
\hline Group oral presentation & $26(33 \%)$ \\
\hline Proctored essay quiz & $26(33 \%)$ \\
\hline Proctored short answer quiz & $20(26 \%)$ \\
\hline Individual oral presentation & $16(21 \%)$ \\
\hline Non-proctored essay quiz & $16(21 \%)$ \\
\hline Proctored multiple-choice quiz & $15(19 \%)$ \\
\hline Non-proctored short answer quiz & $13(17 \%)$ \\
\hline Individual non-paper assignment & $13(17 \%)$ \\
\hline Non-proctored multiple-choice quiz & $9(12 \%)$ \\
\hline Vlog & $3(4 \%)$ \\
\hline Discussion forum & $2(3 \%)$ \\
\hline \multicolumn{2}{|l|}{ Used same methods compared to before pandemic? } \\
\hline Yes & $53(68 \%)$ \\
\hline No & $24(31 \%)$ \\
\hline Unreported & $1(1 \%)$ \\
\hline \multicolumn{2}{|c|}{$\begin{array}{l}\text { Perceived quality of the non-exam related course assessment in comparison to traditional } \\
\text { (face-to-face) classrooms }\end{array}$} \\
\hline Better & $3(4 \%)$ \\
\hline Slightly better & $7(9 \%)$ \\
\hline No difference & $21(27 \%)$ \\
\hline Slightly worse & $39(50 \%)$ \\
\hline Worse & $8(10 \%)$ \\
\hline \multicolumn{2}{|l|}{ Challenges regarding the non-exam related assessment } \\
\hline $\begin{array}{l}\text { Difficulties in determining whether the submitted assignments were individually } \\
\text { carried out by the students }\end{array}$ & $62(79 \%)$ \\
\hline Difficulties in determining the individual learning progress & $40(51 \%)$ \\
\hline Some students needed more time to finish their assignments & $17(22 \%)$ \\
\hline No drawbacks & $6(8 \%)$ \\
\hline
\end{tabular}

\section{Exam-Related Assessment}

Table 5 contains information on questions regarding exam-related assessments. Essay tests were the most utilized type of assessment. About $47 \%$ of the participants reported using either proctored or non-proctored 
essay tests. The majority (63\%) described their perceived quality of the exam as either slightly worse or worse. Furthermore, integrity issues were also observed as the main challenge regarding the exam-related assessment of the online classrooms.

Table 5: Methods, Perceived Quality, and Challenges of the Exam-Related Course Assessment During the COVID-19 Pandemic

\begin{tabular}{|c|c|}
\hline & n (\%) \\
\hline \multicolumn{2}{|l|}{ Exam-related assessment methods } \\
\hline Proctored essay test & $37(47 \%)$ \\
\hline Non-proctored essay tests & $27(35 \%)$ \\
\hline Individual paper assignments & $22(28 \%)$ \\
\hline Proctored multiple-choice and essay tests & $15(19 \%)$ \\
\hline Group paper assignments & $13(17 \%)$ \\
\hline Synchronous group oral presentation & $10(13 \%)$ \\
\hline Proctored multiple-choice test & $8(10 \%)$ \\
\hline Synchronous individual oral presentation & $7(9 \%)$ \\
\hline Non-proctored multiple-choice and essay tests & $2(3 \%)$ \\
\hline \multicolumn{2}{|l|}{ Same methods compared before the pandemic } \\
\hline Yes & $46(59 \%)$ \\
\hline No & $32(41 \%)$ \\
\hline \multicolumn{2}{|l|}{$\begin{array}{l}\text { Perceived quality of the exam-related assessment in comparison to traditional } \\
\text { (face-to-face) classrooms }\end{array}$} \\
\hline Better & $5(6 \%)$ \\
\hline Slightly better & $4(5 \%)$ \\
\hline No difference & $20(26 \%)$ \\
\hline Slightly worse & $36(46 \%)$ \\
\hline Worse & $13(17 \%)$ \\
\hline \multicolumn{2}{|l|}{ Challenges regarding the exam-related assessment } \\
\hline $\begin{array}{l}\text { Difficulties in determining whether the submitted assignments were individually carried } \\
\text { out by the students }\end{array}$ & $59(76 \%)$ \\
\hline $\begin{array}{l}\text { Some of the exam methods utilized during face-to-face instructions were not applicable } \\
\text { for online exams }\end{array}$ & $50(64 \%)$ \\
\hline $\begin{array}{l}\text { Exam duration issues, such as some students starting their exams late due to poor } \\
\text { internet connection }\end{array}$ & $29(37 \%)$ \\
\hline No drawbacks & $6(8 \%)$ \\
\hline $\begin{array}{l}\text { Difficulties in understanding the steps carried out by students in solving some exam } \\
\text { questions }\end{array}$ & $1(1 \%)$ \\
\hline
\end{tabular}

The results indicate that most participants did not have experience conducting online classrooms, although the majority had experience attending online teaching training. A high number of instructors expressed intent in continuing teaching online post-pandemic. Some general challenges encountered by faculty regarding 
online classrooms were associated with the limited communication with the students, followed by inadequate internet access experienced by some students and limited time to transition the instructional methods.

Furthermore, some instructors already used both synchronous and asynchronous delivery methods, although they are still facing challenges in measuring student involvement and difficulties in creating more interactive classes. Moreover, more than half of the participants reported using the same assessment methods, such as essay tests. As indicated in the survey result, the challenges regarding the assessments were associated with difficulties in determining whether the students individually carried out the submitted assignments or exams.

\section{Discussion}

A significant number of participants reported to have received training in using online classrooms, and it was revealed that most IE instructors in Indonesia were relatively new to it. This finding is slightly different from other countries such as the United States, where most higher institutions have online programs (Allen et al., 2015). Therefore, challenges revealed by the Indonesian IE instructors were associated with instructors' lack of experience in conducting online classrooms.

The study revealed the intent of many to continue online teaching after the pandemic. To minimize discrepancies in quality between online and face-to-face instruction, some programs in Indonesia need to start putting more investment in online classroom infrastructure, including pedagogical and technical support (Johnson et al., 2020; Orr et al., 2009; Vlachopoulos, 2020). It is necessary to educate instructors on how to make the online class more interactive using tools such as class gamification platforms like Kahoot and Top Hat to interactive presentation platforms such as Mentimeter (Gokbulut, 2020). Furthermore, providing adequate training and hardware associated with technology to support online teaching could help strengthen the online classroom infrastructure.

The IE instructors reported that inadequate internet access was a significant challenge in conducting online classrooms in Indonesia. The inadequate internet access could be attributed to the fact that not every region in Indonesia has equal internet connection quality. Slightly different from other countries where most citizens inhabit the same land, Indonesians are spread across many islands. Consequently, some infrastructure could be well developed only in an island where the density was very high, such as on Java island (Sandee, 2016; Sujarwoto \& Tampubolon, 2016). Therefore, it would be beneficial if college and university administrators could gather information on where the students lived during the crisis to provide an adapted instructional approach to compensate for their limited internet connection (Holzweiss et al., 2020). Furthermore, many students in Indonesia have low purchasing power that could affect their ability to acquire good internet access (Luschei et al., 2008). Due to the shift of learning to fully online during the pandemic, the Ministry of Education and Culture provided discounted internet subscriptions for college students nationally, and this assistance could be one of the correct countermeasures that should decrease instructional challenges (Ministry of Education and Culture, 2020a).

Integrity was one of the biggest concerns regarding online classroom assessment. The high percentage of reported integrity issues could be associated with the type of exam; essay tests were the most favored assessment methods. In minimizing such issues, instructors need to consider some other solutions, such as using questions with higher-order thinking skills, increasing assessment frequency, and requiring students to sign an academic integrity pledge (Nguyen et al., 2020). Another approach, such as project-based assessment, could also be implemented as an alternative to exam proctoring, for which not all institutions have adequate infrastructure (Halaweh, 2020).

In addition to the implementation of alternative assessment methods, higher education institutions could expand the capability of the existing learning management systems by adding integrity check tools that can help instructors identify potential integrity issues (Baker et al., 2008). However, prior to the LMS capability 
expansion, it is important that universities ensure each instructor has the same computer literacy to minimize technology hurdles when working with the LMS (Rahman et al., 2019).

\section{Limitations of the Study}

Response rate was approximately 30\% of the invited candidates, which is relatively low. Moreover, participants were identified from programs that provided publicly accessed websites and staff email addresses. Consequently, some IE instructors at higher education institutions with inadequate basic IT infrastructure might not be identified as potential participants. Also, the majority of participants were faculty in institutions located on Java island. As described earlier, Java island had the best telecommunication infrastructure among the islands in Indonesia. Therefore, our findings may not be generalized for all IE programs across Indonesia. This study also did not investigate the uses of interactive tools for supporting online teaching, which affected the discussion to respond to the findings on class interaction challenges.

\section{Implications for Practice and Conclusion}

The findings of the study revealed high intent in continuing to teach online. Hence, university management could start by investing more in strengthening the online learning infrastructure and providing training to the instructors. The instructors could be introduced to various assessment methods that can replace traditional essay test that seems problematic to be utilized on online classrooms. 


\section{References}

Adams, S. K. (1984). Ergonomics lab experiments for industrial engineering sophomores. Proceedings of the Human Factors Society Annual Meeting, 28, 173-175. https://doi.org/10.1177/154193128402800218

Allen, I. E., Seaman, J., Hill, P., \& Poulin, R. (2015). Grade level: Tracking online education in the United States. Babson Survey Research Group. https://files.eric.ed.gov/fulltext/ED572778.pdf

Bacow, L., Bowen, W., Guthrie, K., Lack, K., \& Long, M. (2015). Barriers to adoption of online learning systems in U.S. higher education. Ithaka S+R. https://doi.org/10.18665/sr.22432

Baker, R. K., Thornton, B., \& Adams, M. (2008). An evaluation of the effectiveness of turnitin.com as a tool for reducing plagiarism in graduate student term papers. College Teaching Methods \& Styles Journal (CTMS), 4(9), 1-4. https://doi.org/10.19030/ctms.v4i9.5564

Bediang, G., Stoll, B., Geissbuhler, A., Klohn, A. M., Stuckelberger, A., Nko’o, S., \& Chastonay, P. (2013). Computer literacy and e-learning perception in Cameroon: The case of Yaounde Faculty of Medicine and Biomedical Sciences. BMC Medical Education, 13(1), 57-65. https://doi.org/10.1186/1472-6920$\underline{13-57}$

Belawati, T. (2005). The impact of online tutorials on course completion rates and student achievement. Learning, Media and Technology, 3o(1), 15-25. https://doi.org/10.1080/13581650500075520

Britt, R. (2006). Online education: A survey of faculty and students. Radiologic Technology, 77(3), 183-190.

Bunk, J., Li, R., Smidt, E., Bidetti, C., \& Malize, B. (2015). Understanding faculty attitudes about distance education: The importance of excitement and fear. Online Learning, 19(4). 132-142. https://doi.org/10.24059/olj.v19i4.559

Central Bureau of Statistics. (2020). Statistical Yearbook of Indonesia 2020. Badan Pusat Statistik. https://www.bps.go.id/publication/2020/04/29/e9011b3155d45d70823c141f/statistik-indonesia2020.html

COVID-19 Management Task Force. (2020, May 14). Kisi-Kisi Pelaksanaan PSBB DKI Jakarta [Large Scale Social Restrictions Guidance of the Special Capital Region of Jakarta]. Komite Penanganan COVID19 dan Pemulihan Ekonomi Nasional. https://covid19.go.id/p/regulasi/kisi-kisi-pelaksanaan-psbbdki-jakarta-14-mei-2020

Dong, B., Zheng, Q., Yang, J., Li, H., \& Qiao, M. (2009). An E-learning ecosystem based on cloud computing infrastructure. 2009 Ninth IEEE International Conference on Advanced Learning Technologies, 125-127. https://doi.org/10.1109/ICALT.2009.21

Eastmond, D. (2000). Realizing the promise of distance education in low technology countries. Educational Technology Research and Development, 48(2), 100-111. https://doi.org/10.1007/BF02313405

Ginting, D., Djiwandono, P. I., Woods, R., \& Lee, D. (2020). Is autonomous learning possible for Asian students? The story of a MOOC from Indonesia. Teaching English with Technology, 2O(1), 60-79.

Gokbulut, B. (2020). The effect of Mentimeter and Kahoot applications on university students' e-learning. World Journal on Educational Technology: Current Issues, 12(2), 107-116. https://doi.org/10.18844/wjet.v12i2.4814

Gorbiano, M. I. (2020, March 2). BREAKING: Jokowi announces Indonesia's first two confirmed COVID-19 cases. The Jakarta Post. https://www.thejakartapost.com/news/2020/03/02/breaking-jokowiannounces-indonesias-first-two-confirmed-covid-19-cases.html

Halaweh, M. (2020). Are universities using the right assessment tools during the pandemic and crisis times? Higher Learning Research Communications, 11. 1-9. https://doi.org/10.18870/hlrc.v11io.1184 
Harsasi, M. (2015). The use of open educational resources in online learning: A study of students' perception. Turkish Online Journal of Distance Education, 16(3), 74-87. https://doi.org/10.17718/tojde.46469

Holzweiss, P. C., Walker, D. W., Chisum, R., \& Sosebee, T. (2020). Crisis planning for online students: Lessons learned from a major disruption. Online Learning, 24(2), 22-37. https://doi.org/10.24059/olj.v24i2.2135

Ilman, N. M. (Ed.). (2020). Panduan Akademik 2020-Departemen Teknik Mesin dan Industri. Departemen Teknik Mesin dan Industri, FT UGM. https://dtmi.ft.ugm.ac.id/buku-panduan-akademik-dtmi$\underline{2020 /}$

Institute of Industrial \& Systems Engineers. (2019). Industrial and systems engineering BoK. https://www.iise.org/Details.aspx?id=43631

Johnson, N., Veletsianos, G., \& Seaman, J. (2020). U.S. faculty and administrators' experiences and approaches in the early weeks of the COVID-19 pandemic. Online Learning, 24(2), 6-21. https://doi.org/10.24059/olj.v24i2.2285

Kulkarni, V., Kulkarni, S., Satish, J., \& Gaitonde, V. (2017). Attainment of major competencies of programspecific outcome in industrial engineering and simulation lab through open-ended experiment. International Journal of Continuing Engineering Education and Life-Long Learning, 27(3), 183197. https://doi.org/10.1504/IJCEELL.2017.084840

Luschei, T. F., Dimyati, S., \& Padmo, D. (2008). Maintaining e3 -learning while transitioning to online instruction: The case of the Open University of Indonesia. Distance Education, 29(2), 165-174. https://doi.org/10.1080/01587910802154962

Ministry of Education and Culture. (2020a). Bantuan Kuota Data Internet 202O-Kemendikbud [Ministry of Education and Culture-Internet Assistance 2020]. Kementerian Pendidikan Dan Kebudayaan. https://kuota-belajar.kemdikbud.go.id/

Ministry of Education and Culture. (2020b, March 24). Mendikbud Terbitkan SE tentang Pelaksanaan Pendidikan dalam Masa Darurat Covid-19 [Minister of Education and Culture Issued a Circular Letter on the Implementation of Education during the Covid-19 Emergency]. Kementerian Pendidikan Dan Kebudayaan. https://www.kemdikbud.go.id/main/blog/2020/o3/mendikbudterbitkan-se-tentang-pelaksanaan-pendidikan-dalam-masa-darurat-covid19

Ministry of Research, Technology, and Higher Education. (2015). Jumlah Minimal Dosen Di Program Studi dan Sanksi [The Minimum Number of Faculty in a Study Program and The Sanctions]. Kementerian Riset, Teknologi, dan Pendidikan Tinggi. https://www.ristekbrin.go.id/jumlah-minimal-dosen-diprogram-studi-dan-sanksi/

Ministry of Research, Technology, and Higher Education. (2018). Statistik Pendidikan Tinggi Indonesia 2018 [2018 Statistics of Indonesian Higher Education]. Kementerian Riset, Teknologi, dan Pendidikan Tinggi https://pddikti.kemdikbud.go.id/asset/data/publikasi/Statistik\%2oPendidikan\%2oTinggi\%2oIndon esia\%202018.pdf

Myers, C. B., Bennett, D., Brown, G., \& Henderson, T. (2004). Emerging online learning environments and student learning: An analysis of faculty perceptions. Journal of Educational Technology \& Society, $7(1), 78-86$.

Nguyen, A. T., \& Nguyen, N. V. P. (2018). Benchmarking industrial engineering programs. Benchmarking: An International Journal, 25(4), 1194-1212. https://doi.org/10.1108/BIJ-09-2016-0136 
Nguyen, J. G., Keuseman, K. J., \& Humston, J. J. (2020). Minimize online cheating for online assessments during COVID-19 pandemic. Journal of Chemical Education, 97(9), 3429-3435. https://doi.org/10.1021/acs.jchemed.oc00790

Niebuhr, V., Niebuhr, B., Trumble, J., \& Urbani, M. J. (2014). Online faculty development for creating elearning materials. Education for Health, 27(3), 255-261. https://doi.org/10.4103/1357-6283.152186

Nurhudatiana, A., Anggraeni, A., \& Putra, S. (2019). An exploratory study of MOOC adoption in Indonesia. Proceedings of the 20195 th International Conference on Education and Training TechnologiesICETT 2019, 97-101. https://doi.org/10.1145/3337682.3337690

O’Doherty, D., Dromey, M., Lougheed, J., Hannigan, A., Last, J., \& McGrath, D. (2018). Barriers and solutions to online learning in medical education-an integrative review. BMC Medical Education, 18(1), 130141. https://doi.org/10.1186/s12909-018-1240-0

Olori, A. L., \& Dessy, O. O. (2017). Women education in Nigeria: Barriers and distance learning strategies as panacea. Journal of Education and Practice, 8(22), 162-168.

Orr, R., Williams, M. R., \& Pennington, K. (2009). Institutional efforts to support faculty in online teaching. Innovative Higher Education, 34(4), 257. https://doi.org/10.1007/s10755-009-9111-6

Palmer, M. M., Shaker, G., \& Hoffmann-Longtin, K. (2014). Despite faculty skepticism: Lessons from a graduate-level seminar in a hybrid course environment. College Teaching, 62(3), 100-106. https://doi.org/10.1080/87567555.2014.912608

Prodjo, W. A. (2020, January 19). 25 Jurusan dengan Passing Grade Tertinggi di SBMPTN 2019 [25 Programs with the Highest Passing Grade in 2019 SBMPTN]. kompas.com. https://edukasi.kompas.com/read/2020/01/19/19084571/25-jurusan-dengan-passing-gradetertinggi-di-sbmptn-2019?page $=$ all

Rahman, A. A., Arifin, M. A., \& Furqan, A. (2019). Adopting learning management system in Indonesian higher education: The encountering challenges to the transformation. Asian EFL Journal, 23(3), 8397.

Roy, S., \& Covelli, B. (2020). COVID-19 Induced transition from classroom to online mid semester: Case study on faculty and students' preferences and opinions. Higher Learning Research Communications, 11. https://doi.org/10.18870/hlrc.v11io.1197

Sandee, H. (2016). Improving connectivity in Indonesia: The challenges of better infrastructure, better regulations, and better coordination. Asian Economic Policy Review, 11(2), 222-238. https://doi.org/10.1111/aepr.12138

Sari, A. R., Bonk, C. J., \& Zhu, M. (2020). MOOC instructor designs and challenges: What can be learned from existing MOOCs in Indonesia and Malaysia? Asia Pacific Education Review, 21(1), 143-166. https://doi.org/10.1007/s12564-019-09618-9

Savitri, F. N. (2018, April 2). Obituari: Profesor Matthias Aroef, Bapak Teknik Industri Indonesia [Obituary: Professor Matthias Aroef, the Father of Indonesian Industrial Engineering]. Institut Teknologi Bandung. https://www.itb.ac.id/news/read/56589/home/obituari-profesor-matthias-aroef-bapakteknik-industri-indonesia

Siegel, M. (2002). What to do when the teaching lab instruments are too sophisticated for the students? 2002 IEEE International Symposium on Virtual and Intelligent Measurement Systems (IEEE Cat. No.o2EX545), 123-128. https://doi.org/10.1109/VIMS.2002.1009369

Son, J.-B., Robb, T., \& Charismiadji, I. (2011). Computer literacy and competency: A survey of Indonesian teachers of English as a foreign language. Computer-Assisted Language Learning Electronic Journal (CALL-EJ), 12(1), 26-42. 
Sujarwoto, S., \& Tampubolon, G. (2016). Spatial inequality and the internet divide in Indonesia 2010-2012. Telecommunications Policy, 4O(7), 602-616. https://doi.org/10.1016/j.telpol.2015.08.008

Sulistyo-Basuki, L. (2007, January 25). IT and education, the case study of e-learning in Indonesia-E-LIS repository. Korea-ASEAN Academic Conference on Information Revolution and Cultural Integration in East Asia, Ho Chi Minh city, Vietnam. http://eprints.rclis.org/9048/

Surjono, H., Muhtadi, A., \& Wahyuningsih, D. (2017). The implementation of blended learning in multimedia courses for undergraduate students in Indonesia. International Journal of Information and Education Technology, 7, 783-786. https://doi.org/10.18178/ijiet.2017.7.10.972

Vlachopoulos, D. (2020). COVID-19: Threat or opportunity for online education? Higher Learning Research Communications, 1O(1). 16-19. https://doi.org/10.18870/hlrc.v10i1.1179

Watts, L. (2016). Synchronous and asynchronous communication in distance learning: A Review of the literature. Quarterly Review of Distance Education, 17(1), 23-32.

Zainuddin, Z., \& Keumala, C. M. (2018). Blended learning method within Indonesian higher education institutions. Jurnal Pendidikan Humaniora, 6(2), 69-77.

Zuhairi, A., Wahyono, E., \& Suratinah, S. (2006). The historical context, current development, and future challenges of distance education in Indonesia. Quarterly Review of Distance Education, 7(1), 95-101. 


\section{Appendix}

\section{English Translation of the Survey}

1. Did you conduct any online classrooms in Industrial Engineering programs during spring semester (2019/2020) as a response to the social distancing requirement due to the COVID-19 pandemic?
a. Yes
b. No

2. What is your gender?
a. Female
b. Male

3. How old are you?

4. How long have you held a faculty position at any higher education institution?

5. What is the highest degree that you have attained?
a. Bachelor
b. Master
c. Ph.D.

6. What is the highest academic grade that you have held?
a. No grade
b. Lecturer
c. Assistant Professor
d. Associate Professor
e. Professor

7. In what city is your institution located?

8. What is the most recent accreditation rank of your institution?
a. A
b. B
c. C
d. Excellent
e. Very Good
f. Good

9. Please write the name of the course(s) in the industrial engineering programs that you taught during the COVID-19 pandemic?

10. Did you conduct an online classroom prior to the COVID-19 pandemic?
a. Yes
b. No

11. Did you have any form of training regarding online classrooms prior to the COVID-19 pandemic?

a. Yes

b. No

12. Do you feel qualified to conduct online classrooms?
a. Yes
b. No

13. How difficult is conducting online classrooms during the COVID-19 pandemic?

Really difficult $\quad 1$

$\begin{array}{ll}2 \\ 3 \\ \text { Really easy } & 4 \\ & 5\end{array}$


14. What kind of challenges did you encounter when conducting online classrooms during the COVID-19 pandemic? Please select all that apply

- Limited communication with students

- Limited preparation time

- Inadequate teaching technology

- Unfamiliarity with the technology

- Others: ...

15. Do you have any plan to continue teaching online when the COVID-19 pandemic has ended?

a. Yes

b. No

16. What kind of methods did you use in delivering the courses online? Please select all that apply

- Asynchronously using Coursera

- Asynchronously using Google Classroom Video Feature

- Asynchronously using MS Teams

- Asynchronously using Udemy

- Asynchronously using Youtube

- Synchronously using Cisco Webex

- Synchronously using Google Meet

- Synchronously using MS Teams

- Synchronously using Zoom

- Whatsapp Chat

- Whatsapp Voice Note

- Other: ...

17. At what level did the course delivery process using the chosen methods seem effective compared to traditional classrooms?
a. Better
b. Slightly better
c. No differences
d. Slightly worse
e. Worse

18. What kind of challenges did you encounter when delivering the courses using the chosen methods? Please select all that apply

- The lectures became more boring due to difficulties in telling jokes during online lessons

- Lectures became less interactive

- The instructors found difficulties in providing examples, particularly in mathematics

- Some concepts became more difficult to demonstrate or deliver

- Difficulties in understanding students involvement during lectures

- Some technical errors (such as forgetting to mute or unmute one's microphone) happened often

- Instructors encountered issues with their internet connection during the course delivery process

- Other: ... 
19. What kind of methods did you choose for performing non-exam related assessments to the students? Please select all that apply

- Group paper assignments

- Group oral presentations

- Individual non-paper assignment

- Individual oral presentations

- Individual paper assignments

- Proctored essay quizzes

- Proctored multiple-choice quizzes

- Proctored short answer quizzes

- Non-proctored essay quizzes

- Non-proctored multiple-choice quizzes

- Non-proctored short answer quizzes

- Other: ...

20. Did you make use of non-exam related assessment methods when conducting traditional classrooms prior to the pandemic?
a. Yes
b. No

21. At what level did the quality of the non-exam related course assessment using the chosen methods seem effective compared to traditional classrooms?
a. Better
b. Slightly better
c. No differences
d. Slightly worse
e. Worse

22. What kind of challenges did you experience when performing non-exam related assessments using the chosen methods? Please select all that apply

- It was not easy to ensure that the students did their individual assignment without discussing with other their colleagues

- It was difficult to determine students' individual learning achievement

- Students needed more time to submit their assignments

- No drawbacks

- Other:...

23. What kind of methods did you use in performing exam related assessments for the students? Please select all that apply

- Group paper assignments

- Group oral presentations

- Individual non-paper assignment

- Individual oral presentations

- Individual paper assignments

- Proctored essay tests

- Proctored multiple-choice tests

- Proctored combination between essay and multiple-choice tests

- Non-proctored essay tests

- Non-proctored multiple-choice tests

- Non-proctored short answer tests

- Take-home essay tests

- Other:... 
24. Did you utilize the same exam-related assessment methods when conducting traditional classrooms prior to the pandemic?
a. Yes
b. No

25. At what level did the exam-related course assessments seem effective using the chosen methods compared to traditional classrooms?
a. Better
b. Slightly better
c. No differences
d. Slightly worse
e. Worse

26. What kind of challenges did you experience when performing non-exam related assessment using the chosen methods? Please select all that apply

- The approach that was regularly used during traditional classrooms was not directly applicable to the online classrooms

- It was not easy to ensure that the students completed their exam without discussing it with each other

- Some students did start their exam on time, while some had issues with their internet connection towards the end of the exam

- No drawbacks

- $\quad$ Other: ...

The Higher Learning Research Communications (HLRC), is a peer-reviewed, online, interdisciplinary journal indexed in Scopus, ERIC, JGATE and Directory of Open Access Journals (DOAJ). It is an open access journal with an international focus published by Walden University, USA. Its aim is to disseminate both high quality research and teaching best practices in tertiary education across cultures and disciplines. HLRC connects the ways research and best practice contribute to the public good and impact the communities that educators serve. $H L R C$ articles include peer-reviewed research reports, research briefs, comprehensive literature reviews, and books reviews. 